\title{
CEREBRAL CIRCULATION AND METABOLISM IN HYPERTHYROIDISM ${ }^{1}$
}

\author{
BY PERITZ SCHEINBERG 2, 3 \\ (From the Department of Medicine, Duke University School of Medicine, \\ Durham, North Carolina)
}

(Submitted for publication February 18, 1950; accepted, April 17, 1950)

Hyperthyroidism affords an excellent opportunity to study the metabolism of the brain under circumstances in which the general body metabolism is increased and to gain thereby further information concerning the mechanisms which serve to regulate cerebral metabolism and blood flow. In addition, it has long been recognized clinically that psychic manifestations, varying from emotional lability and jitteriness to frank psychosis, not infrequently accompany hyperthyroidism (1$5)$; the nature and pathogenesis of these mental disturbances is a source of considerable dispute, although it is generally agreed that no characteristic pathological changes occur in the brain in this disease (6). The purpose of this report is to record our findings on cerebral metabolism in ten observations on nine patients with hyperthyroidism, studied by the nitrous oxide method of measuring cerebral blood flow (7).

\section{METHOD}

The diagnosis of hyperthyroidism was based on clinical and laboratory criteria. In each instance there was general agreement by several observers that the patient was toxic at the time of the study. The basal metabolic rate was uniformly elevated, and the diagnosis was confirmed pathologically at operation in six of the nine patients studied. The remaining three patients have not yet come to surgery. Five of the nine subjects were studied within two days of their hospital admission and before any treatment was instituted; the remaining four had received propylthiouracil in doses of $300 \mathrm{mg}$. daily for one to three days prior to the study. The duration of the disease varied from three months to two years, but in no instance was cardiac failure present. None of the patients showed true psychoses, but all were irritable, nervous, and emotionally labile, with the typically quickened responses of hyperthyroidism. None showed clinical evidence of cerebral vascular disease.

\footnotetext{
1 This work was supported by a grant from the United States Public Health Service.

2 Fellow, American Heart Association.

3 Present address: University of Miami Medical Research Unit, Veteran's Administration Hospital, Coral Gables, Florida.
}

The nitrous oxide method for measuring cerebral blood flow has been previously described (7), and the modification used in this laboratory of drawing simultaneous "integrated" samples from the artery and internal jugular bulb, rather than five separate samples for each, has been reported, together with values obtained on normal young subjects (8). The oxygen content of arterial and venous blood samples was measured by the spectrophotometric method of Hickam and Frayser (9). Blood sugar values were measured by Nelson's modification of Somogyi's method (10). Each value for arterial-cerebral venous glucose difference is the average of four such differences. Arterial pressure was measured by the auscultatory method every two minutes throughout the blood flow procedure, the arm being held at heart level. Mean arterial pressure was computed by adding one-third the pulse pressure to the diastolic pressure. Cerebral venous oxygen tension was not measured directly, but was computed from the per cent oxygen saturation of the cerebral venous blood by the use of a standard oxyhemoglobin dissociation curve drawn for $\mathrm{pH}$ 7.4. Cerebral oxygen consumption, cerebral glucose consumption, and cerebral vascular resistance were calculated as previously described (8).

\section{RESULTS}

The data are summarized in detail in Table I. No significant changes occurred in any of the cerebral metabolic values, as compared to normals. The cerebral blood flows ranged from 52 to $83 \mathrm{ml} . / \mathrm{min} . / 100 \mathrm{gm}$. brain, with a mean of 67 . The arterial-cerebral venous oxygen difference varied from 4.5 to 6.7 volumes per cent, with a mean of 5.5. The arterial-cerebral venous glucose difference ranged from 5 to $13 \mathrm{mg}$. per cent with a mean of 8.9. Cerebral oxygen consumption varied from 3.2 to $3.9 \mathrm{ml} . \mathrm{O}_{2} / \mathrm{min} . / 100 \mathrm{gm}$. brain, with a mean of 3.6. Cerebral glucose consumption varied from 3.9 to $6.8 \mathrm{mg}$. glucose $/ \mathrm{min} . / 100 \mathrm{gm}$. brain, with a mean of 5.7. The $\frac{\mathrm{A}-\mathrm{V} \text { glucose }}{\mathrm{A}-\mathrm{V} \text { oxygen }}$ ratio showed a wide variation, from 1.06 to 2.00 , with a mean value of 1.59 . The extensive variation is probably related to the errors inherent in the determination of glucose. The value of 1.59 is essentially identi- 
TABLE I

Cerebral metabolic functions in hyperthyroidism

\begin{tabular}{|c|c|c|c|c|c|c|c|c|c|c|c|c|}
\hline Pt. & Age & Sex & BMR & $\begin{array}{l}\text { Cerebral } \\
\text { blood } \\
\text { flow }\end{array}$ & $\begin{array}{l}\text { Arterial- } \\
\text { cerebral } \\
\text { venous } \\
\text { oxygen } \\
\text { difference }\end{array}$ & $\begin{array}{c}\text { Arterial- } \\
\text { cerebral } \\
\text { venous } \\
\text { glucose } \\
\text { difference }\end{array}$ & $\begin{array}{c}\text { Cerebral } \\
\text { oxygen } \\
\text { consump- } \\
\text { tion }\end{array}$ & $\begin{array}{c}\text { Cerebral } \\
\text { glucose } \\
\text { consump- } \\
\text { tion }\end{array}$ & $\frac{\mathrm{A}-\mathrm{V} \text { glucose }}{\begin{array}{c}\mathrm{A}-\mathrm{v} \text { oxygen } \\
\text { ratio }\end{array}}$ & $\begin{array}{c}\text { Mean } \\
\text { arterial } \\
\text { pressure }\end{array}$ & $\begin{array}{c}\text { Cerebral } \\
\text { vascular } \\
\text { resistance }\end{array}$ & $\begin{array}{c}\text { Cerebral } \\
\text { venous } \\
\text { oxygen } \\
\text { tension }\end{array}$ \\
\hline $\begin{array}{l}\text { L. S. } \\
\text { M. B. } \\
\text { H. T. } \\
\text { B. A. } \\
\text { E. R. } \\
\text { H. C. } \\
\text { J. W. } \\
\text { J. S. } \\
\text { W. D. }\end{array}$ & 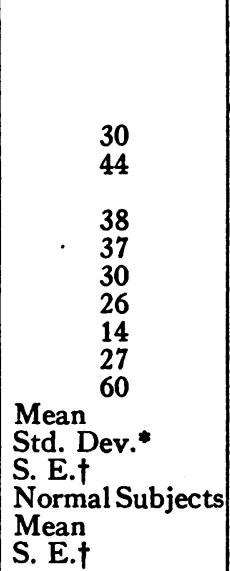 & $\begin{array}{l}\mathbf{M} \\
\mathbf{F} \\
\mathbf{M} \\
\mathbf{M} \\
\mathbf{M} \\
\mathbf{F} \\
\mathbf{M} \\
\mathbf{F} \\
\mathbf{M}\end{array}$ & $\begin{array}{l}+80 \\
+28 \\
+31 \\
+34 \\
+45 \\
+50 \\
+30 \\
+40 \\
+40\end{array}$ & 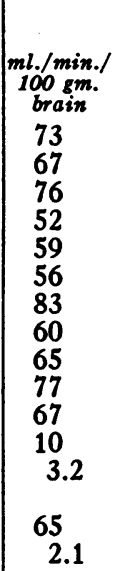 & 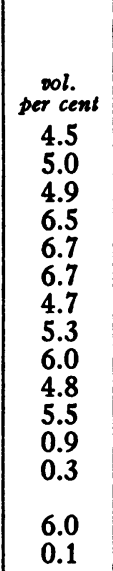 & $\begin{array}{c}\text { mg. } \\
\text { per cent } \\
6 \\
10 \\
8 \\
13 \\
11 \\
12 \\
7 \\
10 \\
7 \\
5 \\
8.9 \\
2.7 \\
0.9 \\
9.9 \\
0.4\end{array}$ & 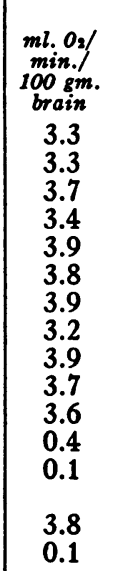 & 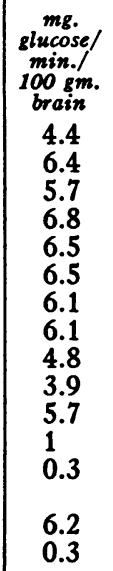 & $\begin{array}{l}1.32 \\
1.92 \\
1.52 \\
2.00 \\
1.66 \\
1.73 \\
1.56 \\
1.93 \\
1.22 \\
1.06 \\
1.59\end{array}$ & $\begin{array}{c}m m . H g \\
70 \\
107 \\
107 \\
93 \\
80 \\
103 \\
79 \\
85 \\
82 \\
83 \\
89\end{array}$ & \begin{tabular}{|c|} 
mm. $\mathrm{Hg} /$ \\
ml. blood \\
100 gm. \\
brain/ \\
min. \\
0.96 \\
1.60 \\
1.41 \\
1.78 \\
1.35 \\
1.84 \\
0.95 \\
1.41 \\
1.26 \\
1.10 \\
1.37 \\
0.3 \\
0.1 \\
\\
1.31 \\
0.04
\end{tabular} & $\begin{array}{l}28 \\
30 \\
34 \\
37 \\
29 \\
31 \\
32\end{array}$ \\
\hline
\end{tabular}

All $P$ values 0.2 or greater.

* Std. Dev. $=$ Standard Deviation $=S=\sqrt{\frac{\mathrm{SX} 2-\frac{(\mathrm{SX})^{2}}{n}}{n-1}}$

†S. E. $=$ Standard Error $=\frac{S}{\sqrt{n}}$

cal to that obtained consistently in this laboratory in a wide variety of patients studied $(8,11-13)$. The cerebral vascular resistance ranged from 0.95 to $1.84 \mathrm{~mm}$. $\mathrm{Hg} / \mathrm{ml}$. blood $/ 100 \mathrm{gm}$. brain $/ \mathrm{min}$., with a mean value of 1.37 . Cerebral venous oxygen tension was not measured in all subjects, but appeared to fall within the normal range.

\section{DISCUSSION}

Though the mean arterial-cerebral venous oxygen difference of 5.5 volumes per cent is not significantly different on statistical analysis from the mean of 6.0 in normal subjects, the distribution in the nine subjects is of interest. In four of the ten observations, the arteriovenous oxygen difference was below 5.0 volumes per cent, as compared to only four of 33 observations below 5.0 volumes per cent in the normal controls. This is an unexpected finding and suggests that either extracerebral contamination of cerebral venous blood has occurred, or that further observations on hyperthyroidism would actually reveal an increased cerebral blood flow and decreased arteriovenous oxygen difference. Although no definite conclusions can be made from the available data, it is felt that previous studies support the former hypothesis. These studies (14) have shown that a degree of contamination of internal jugular blood by extracerebral blood which is not detectable with a normal skin blood flow becomes more obvious as the blood flow to the skin of the face is increased by nicotinic acid. These studies also indicated that increasing the blood flow to a source whose blood is contaminating cerebral venous blood does not necessarily alter the calculated average cerebral oxygen consumption. Evidence of extracerebral contamination without special studies to detect it would be expected to occur in this series more frequently than in normal subjects because of the increased blood flow to the skin in hyperthyroidism. Since small changes in arteriovenous oxygen difference are, in our experience, more easily detectable technically than are small changes in cerebral blood flow, the first noticeable change in the results might well be, as indicated here, in the arterial-cerebral venous oxygen difference. Therefore, though it is possible that facial contamination accounts for some of 
the low arteriovenous oxygen differences in this study, it is felt that the absolute figures given for cerebral oxygen consumption are as accurate as those of the normal control series.

The effect of the administration of thyroid hormone on the respiration of brain tissue of rats, as measured in the Warburg apparatus, has been the subject of study by previous investigators. Cohen found the oxygen consumption to be increased 20 per cent over that of normal brain initially, becoming equal to it in two hours, and 10 per cent lower in four and one-half hours (15). In a similar study, however, Gordon and Heming found a significant increase in the oxygen consumption in the liver, kidney, diaphragm, and heart, but not in the brain, spleen, or testis (16). Our studies would tend to confirm the latter observations, at least as related to man. The finding that cerebral metabolism is not changed from the normal in hyperthyroidism is of considerable positive interest in view of the great increase in body metabolism which occurs in this disease. Studies on the peripheral circulation by the use of plethysmographs and the measurement of skin temperatures $(17,18)$ have revealed an increase in skin and muscle blood flow, decreasing as treatment progressed. The cardiac output is known to be increased in hyperthyroidism $(19,20)$, and the oxygen consumption of the splanchnic area is

TABLE II

Percentage alterations in cardiac output and in hepatic and cerebral metabolic functions in hyperthyroidism (Mean values)

\begin{tabular}{|c|c|c|c|}
\hline & Normal & $\begin{array}{c}\text { Hyperthy- } \\
\text { roidism }\end{array}$ & $\begin{array}{c}\text { Per cent } \\
\text { change }\end{array}$ \\
\hline $\begin{array}{l}\text { Cardiac Index } \\
\left(1 . / \text { min. } / M^{2}\right) \\
\text { Hepatic blood flow } \\
\quad\left(m l . / \text { min. } / M^{2}\right) \\
\text { Cerebral blood flow } \\
\text { (ml./min./100 gm. brain) } \\
\text { Mixed A-V oxygen diff. } \\
\text { (vol. per cent) } \\
\text { Hepatic A-V oxygen diff. } \\
\text { (vol. per cent) } \\
\text { Cerebral A-V oxygen diff. } \\
\text { (vol. per cent) } \\
\text { Total oxygen consumption } \\
\quad(B M R) \\
\text { Splanchnic oxygen consumption } \\
\left.\text { (ml. } 0_{2} / \text { min. } / M^{2}\right) \\
\text { Cerebral oxygen consumption } \\
\text { (ml.02/min./100 gm. brain) }\end{array}$ & $\begin{array}{l}3.97^{*} \\
812^{*} \\
65 \\
3.8^{*} \\
4.3^{*} \\
6.1\end{array}$ & $\begin{array}{c}5.23 \dagger \\
879 \dagger \\
67 \\
3.8 \dagger \\
6.3 \dagger \\
5.5 \\
+54 \dagger \\
55 \dagger \\
3.6\end{array}$ & $\begin{array}{l}+47 \\
+54 \\
+60\end{array}$ \\
\hline
\end{tabular}

* Data obtained from Myers, J. D. (22).

† Data obtained from Myers, J. D. (20). See Text.

(Only statistically significant changes are listed in the Per cent change column). greatly increased in this disease (20). Although adequate studies are not yet available on the kidney, preliminary observations indicate that this organ also shares in the increased blood flow of hyperthyroidism (21). In Table II, the alterations in the cardiac output and the blood flow and metabolism of the splanchnic area and brain in hyperthyroidism are compared. The great increases over normal in cardiac index and splanchnic oxygen consumption are even more striking when compared with the absence of change in the brain. The figures for cardiac output and splanchnic function in hyperthyroidism were taken from Myers (20), whose criteria for the diagnosis of thyrotoxicosis were essentially the same as those used in this study. Three of the patients (B. A., H. C., and J. S.) included in this paper were also included in Dr. Myers' study; in each instance cardiac index and splanchnic oxygen consumption were increased.

We have always assumed that the increase in cardiac output in hyperthyroidism resulted from (1) increased blood flow to the skin to dissipate the increased heat, and (2) increased blood flow to the various organs and tissues in response to their increased metabolism, and that the rise in cardiac output was secondary to a generalized increased demand of the tissues for blood. The collected data in hyperthyroidism certainly do not fit well with such a simple picture. The metabolism in the splanchnic area is increased more than is the blood flow. Neither the brain nor the splanchnic area have a low peripheral resistance to act as a stimulus for an increased cardiac output. More data on the relations between organ blood flow and metabolism in this disease are needed.

The metabolism of the brain is decreased by several pathological conditions and unusual stimuli $(8,11-13,23)$. However, to date, no effective means of increasing cerebral metabolism in man have been found. Apprehension (8), fever (24) and thyrotoxicosis do not increase cerebral metabolism. These observations suggest that cerebral metabolism normally functions at close to its maximum rate and that a large part of the energy used by the brain goes to maintaining the structural and biochemical organization of the brain. Once the facilities are organized and capable of functioning, thinking and the automatic activities of the brain may consume little further energy.

The data reported here do not help us to under- 
stand the psychic manifestations which occur in hyperthyroidism. They do indicate that increased cerebral metabolism, with subsequent cellular exhaustion in the brain, is probably not the cause. A series of observations is needed on patients with true psychoses of hyperthyroidism.

\section{SUMMARY AND CONCLUSIONS}

1. Ten observations on nine patients with hyperthroidism indicate that none of the cerebral metabolic functions varies significantly from the normal in this disease.

2. The increased skin blood flow of hyperthyroidism may have contributed partially to the low arterial-cerebral venous oxygen difference found in four of the observations.

3. The alterations in cardiac output, hepatic blood flow and splanchnic oxygen consumption, and cerebral blood flow and metabolism in hyperthyroidism are compared.

4. It is postulated that cerebral metabolism normally functions at nearly its maximal rate, with a large portion of the energy used by the brain going to maintain its structural and biochemical organization.

5. The psychic manifestations which occur in hyperthyroidism are not related to increased metabolism of the brain.

\section{ACKNOWLEDGMENTS}

The author is indebted to Dr. E. A. Stead, Jr., Duke University School of Medicine, Department of Medicine, for valuable advice in this work. This study was performed with the technical assistance of Miss Frances Morgan, Miss Dorothy Frederick, and Mrs. Louise Allen.

\section{BIBLIOGRAPHY}

1. Dunlap, H. F., and Moersch, F. P., Psychic manifestations associated with hyperthyroidism. Am. J. Psychiat., 1935, 91, 1215.

2. Waldenstrom, J., Acute thyrotoxic enchopalo-ormyopathy, its cause and treatment. Acta med. Scandinav., 1945, 121, 251.

3. Jameison, G. R., and Wall, J. H., Psychoses associated with hyperthyroidism. Psychiat. Quart., 1949, 10, 464.

4. Rulison, E. T., Jr., White, J. D., and Stalker, L. K., Mental disorders associated with hyperthyroidism. Am. J. Surg., 1941, 54, 499.

5. Vokoun, F. J., Toxic goiter and the brain. Mil. Surgeon, 1935, 77, 350.

6. Freeman, W., Personality and the endocrines; a study based upon 1400 quantitative necropsies. Ann. Int. Med., 1935, 9, 444.

7. Kety, S. S., and Schmidt, C. F., The nitrous oxide method for the quantitative determination of cerebral blood flow in man: theory, procedure, and normal values. J. Clin. Invest., 1948, 27, 476.

8. Scheinberg, P., and Stead, E. A., Jr., The cerebral blood flow in male subjects as measured by the nitrous oxide technique. Normal values for blood flow, oxygen utilization, glucose utilization, and peripheral resistance, with observations on the effect of tilting and anxiety. J. Clin. Invest., 1949, 28, 1163.

9. Hickam, J. B., and Frayser, R., Spectrophotometric determination of blood oxygen content. J. Biol. Chem., 1949, 180, 457.

10. Nelson, N., A photometric adaptation of the Somogyi method for the determination of glucose. J. Biol. Chem., 1944, 153, 375.

11. Scheinberg, P., Cerebral blood flow in vascular disease of the brain, with observations on the effects of stellate ganglion block. Am. J. Med., 1950, 8, 139.

12. Scheinberg, P., The cerebral circulation in heart failure. Am. J. Med., 1950, 8, 148.

13. Scheinberg, P., Brannon, E. S., Stead, E. A., Jr., and Warren, J. V., Correlative observations on cerebral metabolism and cardiac output in myxedema. $\mathrm{J}$. Clin. Invest., in press.

14. Scheinberg, P., The effect of nicotinic acid on the cerebral circulation, with observations on extracerebral contamination of cerebral venous blood in the nitrous oxide procedure for cerebral blood flow. Circulation, 1950, 1, 1148.

15. Cohen, R. A., Hyperthyroidism and brain oxidations. Proc. Soc. Exper. Biol. \& Med., 1935, 32, 1446.

16. Gordon, E. S., and Heming, A. E., The effect of thyroid treatment on the respiration of various rat tissues. Endocrinology, 1944, 34, 353.

17. Stewart, H. J., and Evans, W. F., The peripheral blood flow in hyperthyroidism. Am. Heart J., 1940, 20, 715.

18. Eichna, L. W., and Wilkins, R. W., Blood flow to forearm and calf; IV. Thyroid activity: observations on the relation of blood flow to BMR. Bull. Johns Hopkins Hosp., 1941, 68, 512.

19. Fullerton, C. W., and Harrop, G. A., Jr., Cardiac output in hyperthyroidism. Bull. Johns Hopkins Hosp., 1930, 46, 203.

20. Myers, J. D., Brannon, E. S., and Holland, B. C., A correlative study of the cardiac output and the hepatic circulation in hyperthyroidism. J. Clin. Invest., 1950, 29, 1069.

21. Merrill, A. J., Personal communication.

22. Myers, J. D., The hepatic blood flow and splanchnic oxygen consumption of man-their estimation from urea production or bromsulphalein excretion during catheterization of the hepatic veins. J. Clin. Invest., 1947, 26, 1130.

23. Kety, S. S., Polis, B. D., Nadler, C. S., and Schmidt, C. F., The blood flow and oxygen consumption of the human brain in diabetic acidosis and coma. J. Clin. Invest., 1948, 27, 500.

24. Patterson, J., Personal communication. 